\title{
Ceilometer evaluation of the eastern Mediterranean summer boundary layer height - first study of two Israeli sites
}

\author{
Leenes Uzan ${ }^{1,2}$, Smadar Egert ${ }^{1}$, and Pinhas Alpert ${ }^{1}$ \\ ${ }^{1}$ Department of Geosciences, Raymond and Beverly Sackler Faculty of Exact Sciences, Tel Aviv University, \\ Tel Aviv, 6997801, Israel \\ ${ }^{2}$ Associations of Towns for Environmental Protection (Sharon-Carmel), Hadera, 3850100, Israel \\ Correspondence to: Leenes Uzan (leenesu@gmail.com)
}

Received: 13 March 2016 - Published in Atmos. Meas. Tech. Discuss.: 12 May 2016

Revised: 5 August 2016 - Accepted: 16 August 2016 - Published: 7 September 2016

\begin{abstract}
Active remote-sensing instruments, such as ceilometers, have been shown to be potentially useful for the investigation of the behavior of the atmospheric mixing layer height (MLH). For the first time ever, high-resolution measurements of backscatter intensity, taken from two CL31 ceilometers situated inland and onshore of Israel, have enabled evaluation of the mean diurnal cycle of the MLH in the eastern Mediterranean region. Although the Israeli summer synoptic conditions are considered to be quite stable, results for the summer season (July-August 2014) showed the inland MLH to be about $200 \mathrm{~m}$ higher than the MLH at the onshore site, situated only $7.5 \mathrm{~km}$ away. The prevailing influence of the sea breeze front (SBF), as it progresses inland, is presented by the ceilometer plots. Complementing results were found between the radiosonde profiles and the adjacent ceilometer at the inland site of Beit Dagan. In contrast to the expected regularity of clear skies during the Israeli summer, the ceilometers revealed significant cloud cover throughout the day, with higher presence onshore. Assessment of cloud thickness in further research would serve to improve the evaluation of the MLH evolution.
\end{abstract}

\section{Introduction}

A thorough understanding of the main properties of the atmospheric boundary layer (ABL), such as height and temporal evolution, and the factors affecting these properties, is essential for meteorological forecasting, climate studies, and in particular, air-quality assessment (Angelini et al., 2009). Air pollution, its dispersion, and its extent must be understood by defining the nature of the mixing layer height (MLH) in accordance with diurnal evolution (Tang et al., 2015; Ludwig, 1983). In order to develop suitable criteria to provide warnings against adverse ambient conditions, it is important to evaluate the processes governing the ambient atmospheric variations. Usually, such predictions are conducted with numerical weather prediction models (Leventidou et al., 2013). However, the feasibility and accuracy of these models is dependent on calibration by comparison with actual field measurements (Van der Kamp et al., 2010). Most beneficial are direct measurements in high temporal and spatial resolution. Such measurements enable simulation of atmospheric phenomena and distinguish evolvement at its early stage.

Previous studies suggest using more than one remotesensing technique in order to overcome the deficiencies of individual instruments (Cohn and Agenvine, 2004; Emeis et al., 2008; Chuen-Meei et al., 2010). In such research, however, it must be taken into account that each instrument has advantages and limitations in measuring the parameters of specific meteorological phenomena. Overall, a combination of several techniques (Schween et al., 2014; Wiegner et al., 2006) offers the opportunity to follow the whole diurnal cycle of MLH (Dayan and Lifshitz-Golden, 2002).

Meteorological measurements of the temperature profiles in Israel are performed by radiosondes (RS) twice a day, at 00:00 coordinated universal time (UTC) and 12:00 UTC at a single point in Beit Dagan (longitude: $34.81^{\circ} \mathrm{E}$, latitude: $32.01^{\circ} \mathrm{N}$, flat terrain, $7.5 \mathrm{~km}$ from the shoreline). Profiles from a single radiosonde only provide rough estimates of the MLH, due to the arbitrary ascents in thermals or between thermals (Dayan and Koch, 1992; Leventidou et 


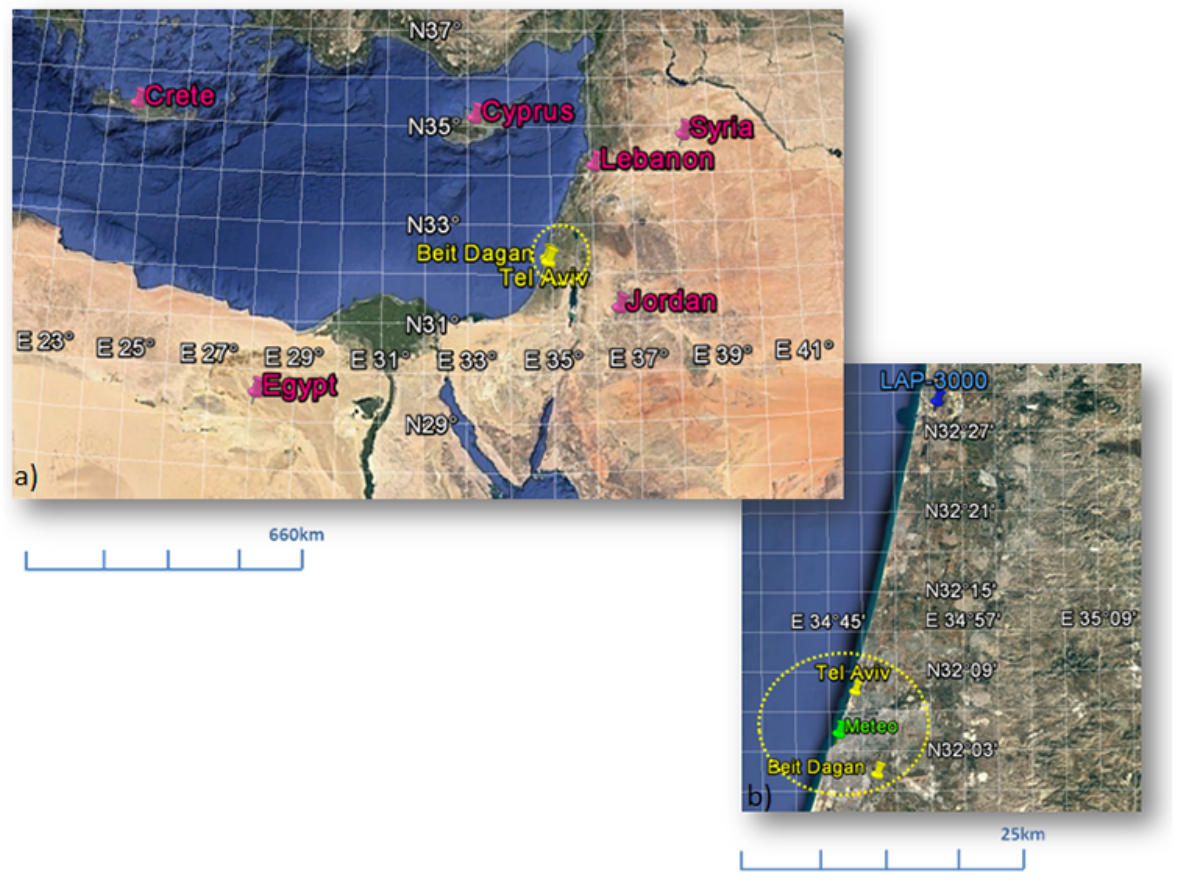

Figure 1. Google Earth map of the eastern Mediterranean, with indication of the ceilometers in Tel Aviv and Beit Dagan (a). Zoomed-in image with indications of the LAP-3000 acoustic radar site and the onshore meteorological monitoring station (b).

al., 2013). Stationary ground-based remote sensing is more frequent but detects the MLH temporal resolution rather than spatial horizontal properties. This paper focuses on two CL31 ceilometers (Kotthaus et al., 2016), onshore and inland. These ceilometers are the first to have been deployed in Israel. (It is expected that a large number of ceilometers will be deployed throughout Israel, according to the authorities' requirements.) Of greatest relevance was the disparity in the mean diurnal cycle of the MLH between two measuring sites - which were only $7.5 \mathrm{~km}$ apart (Fig. 1).

In the following section we give an overview of the ceilometers' parameters, the location of the measuring sites, and a technical description of the analysis methodology. Section 3 presents the results, a comparison with the WRFChem model (example), adjacent radiosonde profiles, and cloud cover detection. Conclusions and discussion are given in Sect. 4.

\subsection{Instrument and data evaluation}

\subsection{CL31 ceilometer}

Research from the last decade (Haeffelin et al., 2012; Emeis et al., 2008; Emeis and Schäfer, 2006; Münkel et al., 2004; Cohn and Agenvine, 2000) has analyzed the vertical aerosol distribution as it adapts rapidly to the changing thermal structure of the boundary layer. This adaptation characteristic allows aerosols to be used as tracers for the determination of the atmospheric MLH. Active remote-sensing instruments, such as ceilometers (Wiegner et al., 2014), produce attenuated backscatter plots directly relative to the atmospheric aerosol content, and are therefore potentially useful for investigation of the behavior of the atmospheric MLH. The Vaisala CL31 ceilometer is a pulsed elastic micro lidar (light detection and ranging), employing an indium gallium arsenide (InGaAs) laser diode transmitter of near-infrared wavelength $\left(910 \mathrm{~nm} \pm 10 \mathrm{~nm}\right.$ at $\left.25^{\circ} \mathrm{C}\right)$. In order to provide a sufficient signal-to-noise ratio, a repetition rate of $10 \mathrm{kHz}$ of short pulses is emitted to the atmosphere, in a measuring interval of 2s (Vaisala ceilometer CL31 user's guide). The backscatter transmissions collected by an avalanche photodiode receiver are averaged to produce an individual attenuated backscatter profile within a reporting interval of 2-120 s. The high resolution of the time and height data, as measured by the two ceilometers, is shown in Table 1.

In this study, we examine results for the summer season (July-August) of 2014, from two ceilometers located in the eastern Mediterranean (EM) in Israel (Fig. 1). Israel (29$33^{\circ} \mathrm{N}$ north of the desert belt) is characterized by a dry, hot, and humid summer, with a prevailing synoptic system of the Persian trough (Alpert et al., 2004), creating a constant MLH less than $1000 \mathrm{~m}$ above ground level (a.g.l.) (Dayan and Lifshitz-Golden, 2002; Lieman and Alpert, 1993). As a result, vertical air-pollution dispersion of local tall stacks is limited, causing plume fumigation and a reduction of air quality at ground level (Uzan and Alpert, 2012).

The analysis was based on two measurement sites: onshore in Tel Aviv (TLV) and inland in Beit Dagan (BD). The 
Table 1. Ceilometer CL31 parameters.

\begin{tabular}{lllllll}
\hline Name & $\begin{array}{l}\text { Time } \\
\text { resolution }\end{array}$ & $\begin{array}{l}\text { Height } \\
\text { resolution }\end{array}$ & $\begin{array}{l}\text { Height } \\
\text { range }\end{array}$ & $\begin{array}{l}\text { Measured } \\
\text { time }\end{array}$ & $\begin{array}{l}\text { Wavelength } \\
\text { (center) }\end{array}$ & $\begin{array}{l}\text { Repetition } \\
\text { rate }\end{array}$ \\
\hline $\begin{array}{l}\text { TLV onshore } \\
\text { BD inland }\end{array}$ & $16 \mathrm{~s}$ & $10 \mathrm{~m}$ & $0-4.5 \mathrm{~km}$ & UTC & $910 \mathrm{~nm}$ & $10 \mathrm{kHz}$ \\
$0-7.7 \mathrm{~km}$ & UTC +2 & $910 \mathrm{~nm}$ & $10 \mathrm{kHz}$ \\
\hline
\end{tabular}

Table 2. Ceilometer CL31 location.

\begin{tabular}{lllcl}
\hline Name & Location & Long./Lat. & Distance from the shoreline & Height (a.g.l.) \\
\hline TLV onshore & Tel Aviv & $34.78 / 32.11$ & $0.05 \mathrm{~km}$ & $5 \mathrm{~m}$ \\
BD inland & Beit Dagan & $34.81 / 32.01$ & $7.5 \mathrm{~km}$ & $33 \mathrm{~m}$ \\
\hline
\end{tabular}
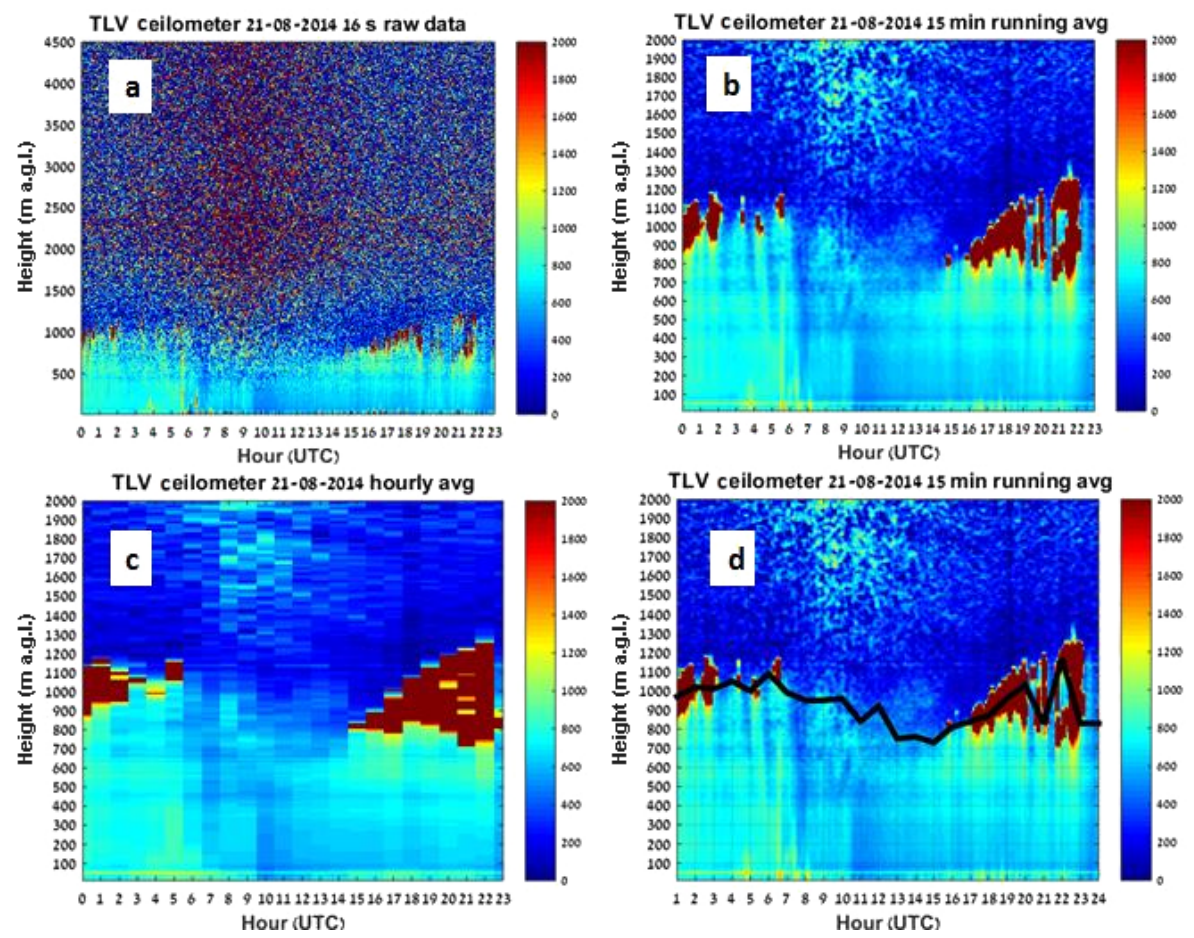

Figure 2. Stages of daily ceilometer evaluation. (a) Raw data plot based on attenuated backscatter (units $10^{-6} \mathrm{~m}^{-1} \mathrm{sr}^{-1}$ ), taken every $16 \mathrm{~s}$; (b) 15 min running average plot to reduce noise; (c) hourly averaged profiles; (d) the assessed diurnal MLH (black line) overlaying panel (b) for hours 01:00-24:00 UTC.

onshore TLV ceilometer is located $5 \mathrm{~m}$ a.g.l. and $50 \mathrm{~m}$ from the shoreline of the central coast of Israel. The inland BD ceilometer is located $33 \mathrm{~m}$ a.g.l. and $7.5 \mathrm{~km}$ from the shoreline, $12 \mathrm{~km}$ southeast from the TLV ceilometer. Details of the measuring sites of the ceilometer are shown in Table 2.

Both locations are considered flat terrain, with relative humidity ranging between 50 and $90 \%$ at the BD site and 65 and $90 \%$ at the TLV site. Considering the wavelength of the CL31 ceilometer $(910 \mathrm{~nm})$, Wiegner and Gasteiger (2015) noted that the signals must be corrected for water vapor absorption in order to derive particle backscatter coefficients. For the determination of the MLH and the detection of aerosol layers, however, this effect can be ignored; even absolute calibration of the signals is not mandatory.

\subsection{Analysis technical description}

The daily ceilometer output profiles, produced as ".his" files, were processed as daily plots for a first impression, in order to define the height range of the MLH evaluation. An example of the process for the data received on 21 August 2014 is given in Fig. 2. The ceilometer TLV backscatter plot between 0 and $4.5 \mathrm{~km}$ reveals that the MLH is less than $2 \mathrm{~km}$ a.g.l. (Fig. 2a). Therefore, the next stage focuses on the height range of $0-2 \mathrm{~km}$. To reduce the noise effect visible in raw 
WRF-Chem vs. ceilometers for dust penetration on 02.03.14

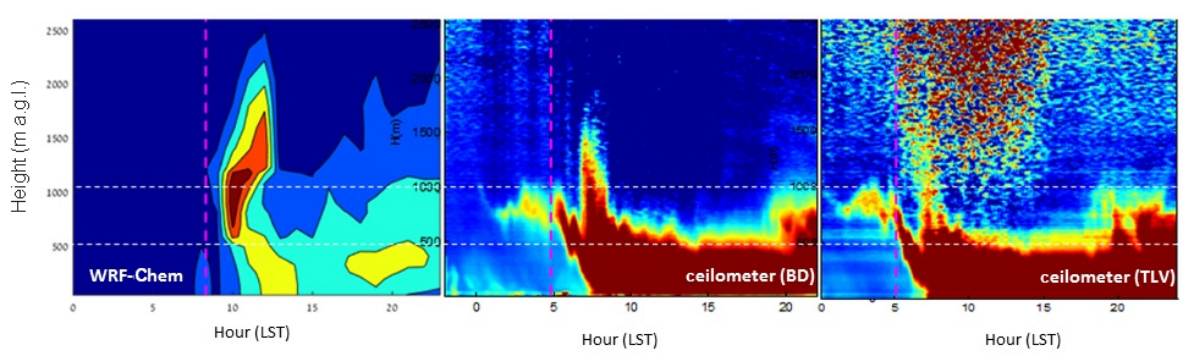

Figure 3. Comparison of the dust storm event over Israel on 2 March 2014. Dust loads of $\mathrm{PM}_{10}\left(\mu \mathrm{g} \mathrm{m}{ }^{-3}\right)$ processed by the WRF-Chem model version 3.5.1 for $10 \mathrm{~km}$ resolution (left panel), 15 min running average of inland ceilometer in Beit Dagan (middle panel), and onshore ceilometer in Tel Aviv (right panel). To facilitate the comparison between the three plots, horizontal lines were added to indicate the heights 500 and $1000 \mathrm{~m}$ a.g.l. and a vertical line was added to indicate the entrance time of the dust front. The timescale is local standard time (LST), which equals UTC +2 . (In the right plot, the strong backscatter intensity in the upper level between 05:00 and 15:00 LST is noise owing to poor maintenance.)

data plots, the backscatter profiles were averaged with $15 \mathrm{~min}$ running averages for the relevant height range (Fig. 2b). The profiles were averaged hourly for clear days (Fig. 2c). This was deemed sufficient; however, for cloudy days, half-hourly average profiles were created. (Later on, the half-hourly average profiles were largely employed.)

Each profile was normalized for wavelet covariance transform (WCT) calculations. WCT is a measure of the similarity of the range-corrected lidar backscatter signal and the Haar function. The Haar function, as established and described by Baars et al. (2008), calculates irregularities along a profile of defined steps. The WCT was implanted in a MATLAB script, to calculate peak values along the normalized profiles by using three simultaneous scenarios: multi-cloud layers, single cloud layers, and clear skies. The evaluation output was plotted and expressed as the diurnal cycle of the MLH (a black line overlaying the 15 min running average plot in Fig. 2d). Finally, the calculated MLH was compared between ceilometers and radiosonde profiles, as discussed in the results.

\section{Results}

To analyze the diurnal variations in the MLH, the highresolution data output of the ceilometers was referenced to the prevailing synoptic system and geostrophic wind, based on National Centers for Environmental Predictions (NCEP) synoptic maps (1000, 850, and $700 \mathrm{mb}$ maps at 00:00, 06:00, 12:00, and 18:00Z), sea breeze front (SBF) entrance time, cloud presence, HYSPLIT back trajectories (500, 1500, $3000 \mathrm{~m}$ a.g.l. over a $24 \mathrm{~h}$ period), the Tel Aviv University (TAU) Desert Dust Model (Carnevale et al., 2012), and the Weather Research and Forecasting model (WRF-Chem version 3.5.1). This resulted in fine tuning of the aforementioned WCT algorithm. The analysis of the diurnal variations, with reference to the various respective functions as outlined above, demonstrates the advantages of the highresolution data output of the ceilometer.

\subsection{WRF model}

Figure 3 presents a dust storm evolution over Israel on 2 March 2014, as measured by ceilometers and the WRFChem model. The dust concentrations calculated by the WRF-Chem model (Flaounas et al., 2016) produced results for particulate matter with an aerodynamic diameter less than $10 \mu \mathrm{m}$ (PM10). The WRF-Chem 3.5.1 version was configured with 32 vertical levels up to $50 \mathrm{hPa}, 20$ of them within the lowest $2 \mathrm{~km}$, and 2 nested domains, with 30 and $10 \mathrm{~km}$ grid spacing. Simulations were initialized and forced with NCEP's Global Final Analysis and provided at a horizontal resolution of $1^{\circ}$. The model was initialized with zero dust distributions. The dust emission scheme that was used is the GOCART model, and parameterization was developed and incorporated in WRF-Chem by the Air Force Weather Agency (AFWA).

The WRF-Chem model revealed a dust front over $1000 \mathrm{~m}$ a.g.l. around 09:00 local standard time (LST). The onshore (TLV) and inland (BD) ceilometers revealed dust penetrating downward up to $500 \mathrm{~m}$ a.g.l. at 05:00 LST. (In March LST equals UTC + 2.) Furthermore, a dust "tail" visible in the ceilometer plots at $800 \mathrm{~m}$ a.g.l. before 05:00 LST had not been identified by the WRF-Chem model. The WRF-Chem model calculated a dust "torch" between 1200 and $2500 \mathrm{~m}$ a.g.1. at 10:00-13:00 LST. This phenomenon was visible mainly in the inland (BD) ceilometer $3 \mathrm{~h}$ earlier, between 07:00 and 09:00 LST, at lower heights of 600$1500 \mathrm{~m}$ a.g.l. We believe these differences, which are most important for aviation, are merely due to the WRF-Chem coarse spatial resolution $(10 \mathrm{~km})$ and the fact that the model input is based on natural dust as the only source for atmospheric aerosols. 

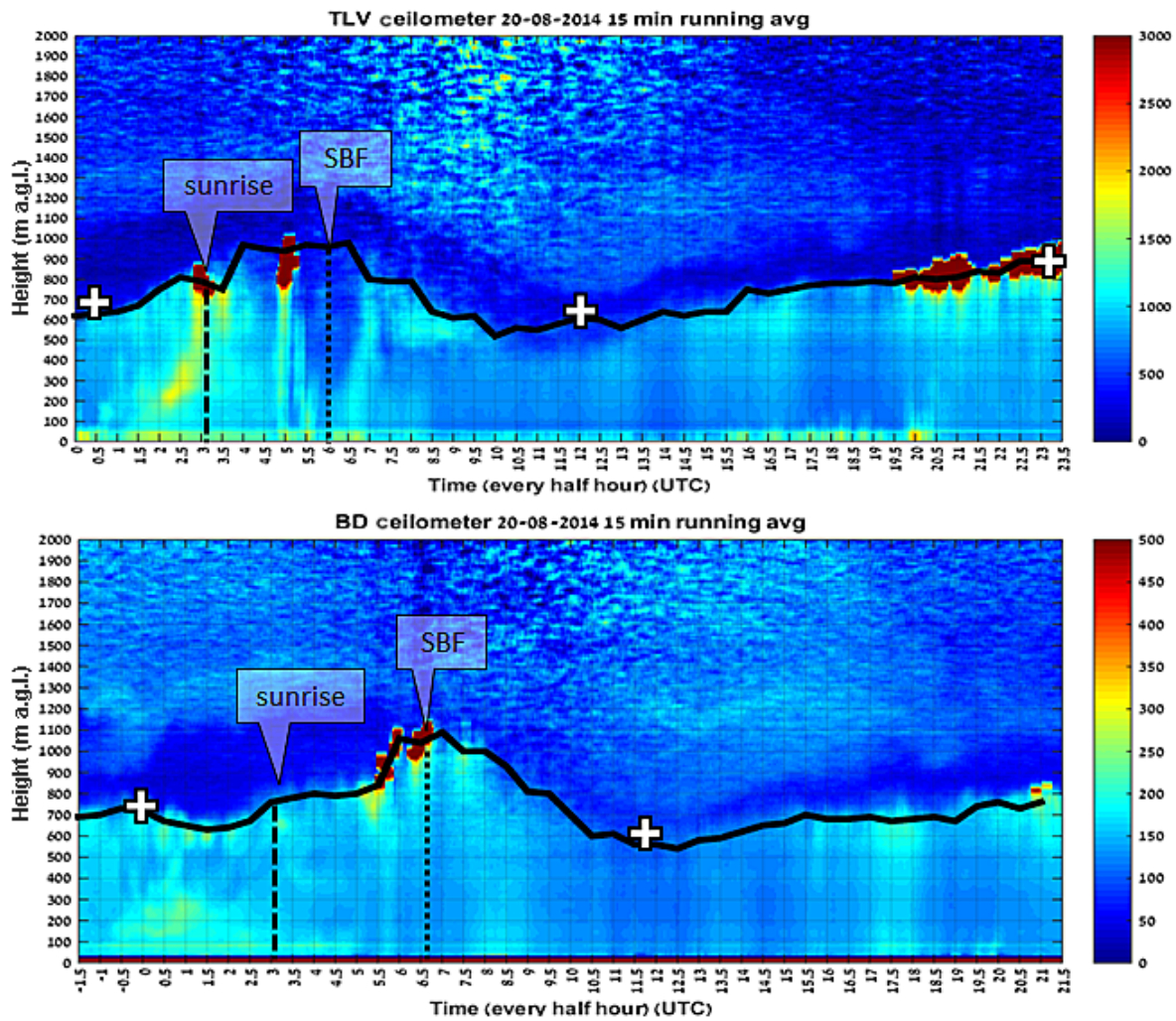

Figure 4. Diurnal MLH (solid black line) on 20 August 2014 for BD and TLV. The MLH is plotted on the half-hourly averaged plots of attenuated backscatter (units $10^{-6} \mathrm{~m}^{-1} \mathrm{sr}^{-1}$ ). The BD plot is shifted by $2 \mathrm{~h}$ to coincide with UTC time. The plot includes indications of the sunrise, the SBF entrance time, and the MLH based on the 00:00 and 12:00 UTC radiosonde profiles in the BD site (indicated by the white crosses).

\subsection{MLH evolution}

Examples of a single day evolvement are given for $20 \mathrm{Au}-$ gust 2014 (Fig. 4) and 13 August 2014 (Fig. 5). Calculation of SBF entrance time, following the Alpert and RabinovichHadar (2003) method, based on the ambient temperature, relative humidity, wind speed, and wind direction, was measured $6.5 \mathrm{~km}$ south of the TLV site by a meteorological monitoring station at $10 \mathrm{ma}$ a.g.l. and $100 \mathrm{~m}$ from the shoreline (Fig. 1). This calculation was then checked against the output of the TLV ceilometer. Analysis revealed that the SBF entered the TLV site at 06:00 UTC on both days.

In order to create a consistent observation between the TLV ceilometer and the BD ceilometer, the SBF progress inland was assessed by the wind speed at $300 \mathrm{~m}$ a.g.l., as suggested by Atkinson (1981). The wind speed of $5 \mathrm{~m} \mathrm{~s}^{-1}$ was estimated by the radiosonde profiles of 12:00 UTC in the BD site and wind profiles as provided by Uzan (2007), using a LAP-3000 acoustic radio detection and ranging instrument (radar). The LAP-3000 profiler, situated $40 \mathrm{~km}$ north of the TLV site and $3.5 \mathrm{~km}$ east of the shoreline (Fig. 1), was a three-beam pulse-Doppler radar of $0.232 \mathrm{~m}$ wavelength, $1290 \mathrm{Mhz}$, reporting wind speed and direction every $60 \mathrm{~m}$ between 127 and $1000 \mathrm{~m}$ a.g.l. The radio acoustic sounding system (RASS) added to the LAP-3000, and provided profiles of virtual temperature data every $100 \mathrm{~m}$ between 144 and $1000 \mathrm{~m}$ a.g.l. The wind speed estimation was based on a mean average of about 700 profiles of wind speed and wind direction, in the years 1997-1999 and 2002-2005.

With a $5 \mathrm{~m} \mathrm{~s}^{-1}$ wind speed it would take the SBF approximately 25 min to advance from the TLV site $7.5 \mathrm{~km}$ inland to the BD site. This calculation fits accurately with the time the MLH began to subside on 20 August 2014 (Fig. 4), causing subsidence of the MLH at 06:30 UTC in the BD site. The rate of the MLH subsidence was calculated by the MLH height difference from SBF entrance time (dotted line in Figs. 4 and 5) and the time of the lowest MLH. Calculations given in Table 3 show that the MLH subsidence rate was even at both measuring sites on 20 August 2014.

In contrast, on the day of 13 August 2014, a different development was observed (Fig. 5, Table 4). The SBF entered the TLV site at 06:00 UTC and was identified in the BD site at 08:00 UTC, an hour and a half later than calculated. One explanation is the intensity and direction of the gradient wind, which may have hindered SBF development. The $925 \mathrm{mb}$ NCEP synoptic maps at the SBF-approximated entrance time (06:00 UTC) reveal this effect, with northern 

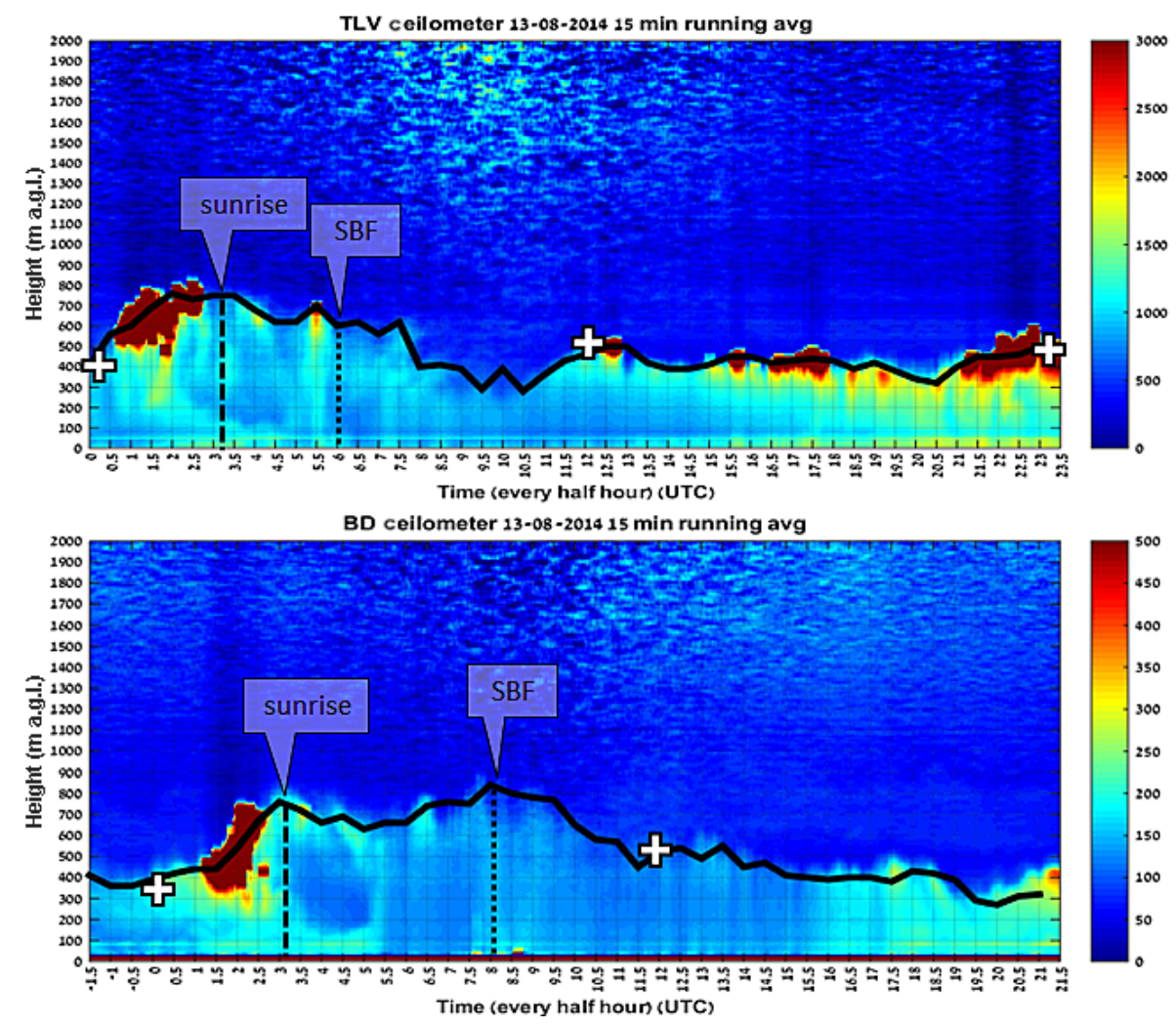

Figure 5. Same as Fig. 4 but for 13 August 2014.

Table 3. Mixed layer height rate of subsidence on 20 August 2014.

\begin{tabular}{lll}
\hline Ceilometer site & $\begin{array}{l}\text { TLV } \\
\text { onshore }\end{array}$ & $\begin{array}{l}\text { BD } \\
\text { inland }\end{array}$ \\
\hline $\begin{array}{l}\text { MLH at SBF entrance time } \\
\text { (m a.g.l.) }\end{array}$ & 900 & 1050 \\
$\begin{array}{l}\text { Lowest MLH after SBF entrance } \\
\text { (m a.g.l.) }\end{array}$ & 500 & 550 \\
$\begin{array}{l}\text { SBF entrance time (UTC) } \\
\text { Time of lowest MLH after }\end{array}$ & $06: 00$ & $06: 30$ \\
$\begin{array}{l}\text { SBF entrance (UTC) } \\
\text { Rate of MLH subsidence }\left(\mathrm{m} \mathrm{h}^{-1}\right)\end{array}$ & $10: 00$ & $11: 30$ \\
\hline
\end{tabular}

winds of $4.3 \mathrm{~m} \mathrm{~s}^{-1}$ compared to the weak northwest wind of $1.6 \mathrm{~m} \mathrm{~s}^{-1}$ on 20 August 2014 (Table 5). Moreover, the TLV MLH on 13 August 2014 began at $400 \mathrm{~m}$ a.g.l., while on 20 August 2014, the MLH extended up to $650 \mathrm{~m}$ a.g.l. Following Atkinson (1981), it is understood that the stable atmosphere of 13 August 2014 caused the lower MLH, which in turn suppressed the sea breeze vertical circulation, reducing the SBF intensity and progress.

The mean diurnal cycle of the summer MLH, as detected by the onshore and inland ceilometers, is presented in Fig. 6. The high-resolution MLH (averaged hourly) demonstrates the following process. After sunrise (around 03:00 UTC), the
Table 4. Mixed layer height rate of subsidence on 13 August 2014.

\begin{tabular}{lll}
\hline Ceilometer site & $\begin{array}{l}\text { TLV } \\
\text { onshore }\end{array}$ & $\begin{array}{l}\text { BD } \\
\text { inland }\end{array}$ \\
\hline $\begin{array}{l}\text { MLH at SBF entrance time } \\
\text { (m a.g.l.) }\end{array}$ & 600 & 800 \\
$\begin{array}{l}\text { Lowest MLH after SBF entrance } \\
\text { (m a.g.l.) }\end{array}$ & 300 & 450 \\
$\begin{array}{l}\text { SBF entrance time (UTC) } \\
\text { Time of lowest MLH after }\end{array}$ & $06: 00$ & $08: 00$ \\
$\begin{array}{l}\text { SBF entrance (UTC) } \\
\text { Rate of MLH subsidence }\left(\mathrm{m} \mathrm{h}^{-1}\right)\end{array}$ & $\sim 55: 30$ & $11: 30$ \\
\hline
\end{tabular}

Table 5. Wind $(U, V)$ in $925 \mathrm{mb}$ at 06:00 UTC (09:00 LST) from NCEP Reanalysis Pressure Level GrADS.

\begin{tabular}{lrrr}
\hline Date & $\begin{array}{r}U \text { wind } \\
\left(\mathrm{m} \mathrm{s}^{-1}\right)\end{array}$ & $\begin{array}{r}V \text { wind } \\
\left(\mathrm{m} \mathrm{s}^{-1}\right)\end{array}$ & $\begin{array}{r}\operatorname{Dir}\left(^{\circ}\right) / \\
\text { Speed }\left(\mathrm{m} \mathrm{s}^{-1}\right)\end{array}$ \\
\hline 13 August 2014 & 0.5 & -4.25 & $007 / 4.3$ \\
20 August 2014 & 0.5 & -1.5 & $342 / 1.6$ \\
\hline
\end{tabular}

ground warms up and the surface nocturnal boundary layer breaks. Thermals inflate the ABL (around 05:00 UTC), recreating the morning mixed layer. A developed SBF moves in- 


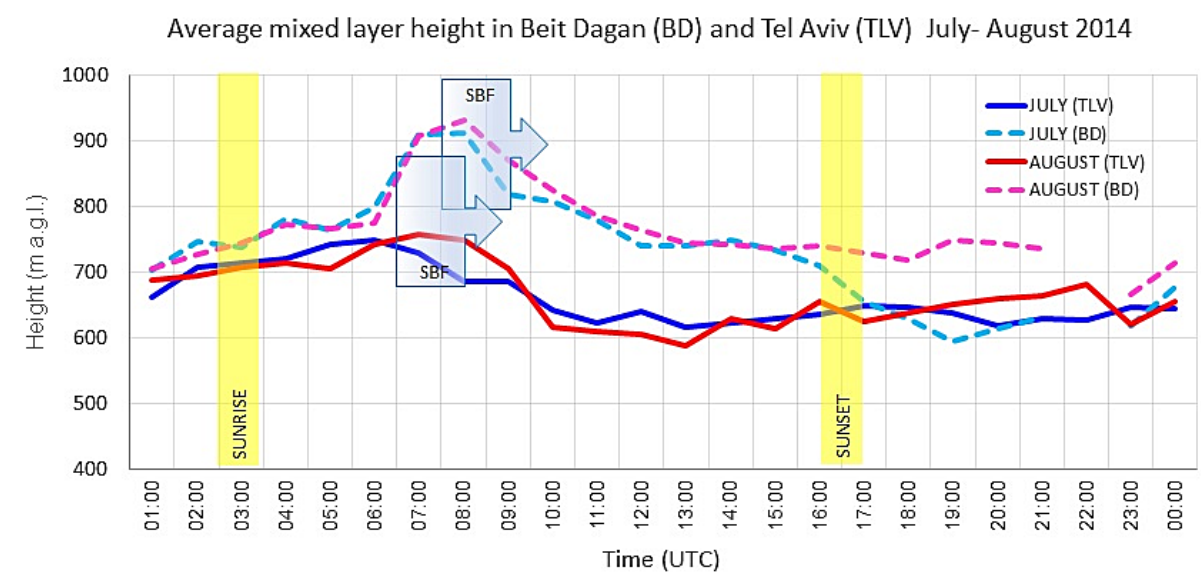

Figure 6. The hourly average of the eastern Mediterranean summer MLH, at the onshore site in Tel Aviv (solid lines) and the inland site in Beit Dagan (dashed lines,) between July (blue and pale blue lines) and August (red and pink lines) 2014. The MLH was evaluated by the CL31 ceilometer measurements at both sites, taken over 20 days in July and 24 days in August in the BD site, and 30 days in July and 30 days in August in the TLV site. Indications of the sunrise, sunset, and the SBF are given. Data provided from the BD site are comprised of $23 \mathrm{~h}$ of measurements on UTC +2 timescale; therefore in order to compare to the $24 \mathrm{~h}$ of TLV site measured on UTC timescale, the hour of 22:00 UTC is missing for BD measurements.

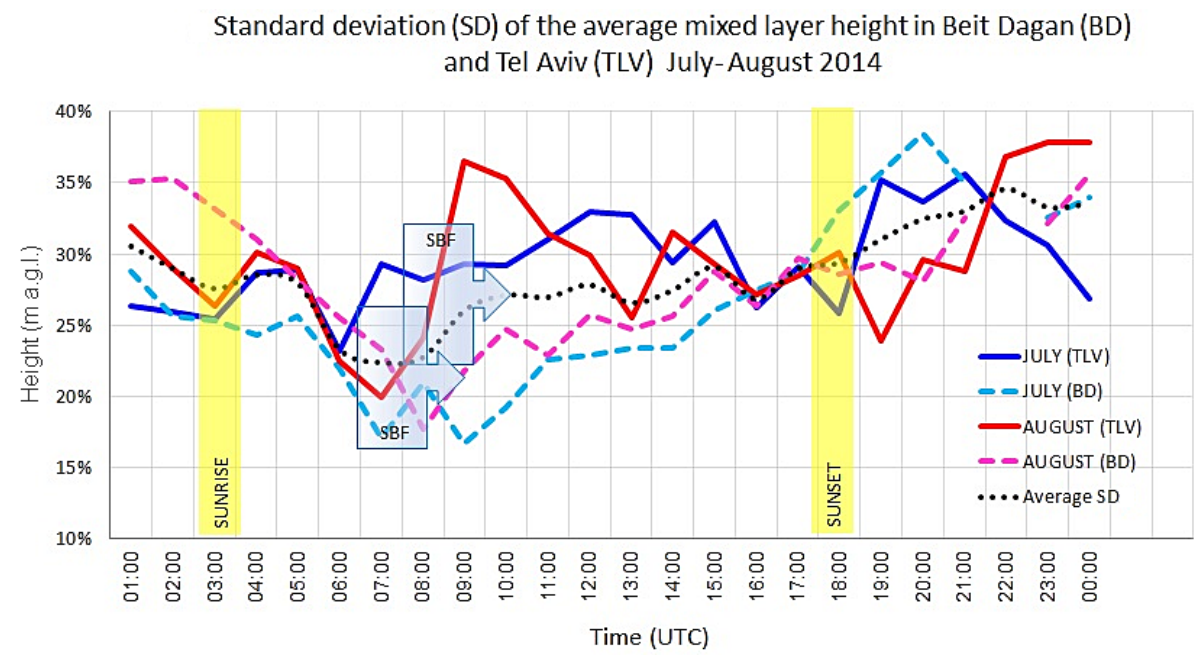

Figure 7. The standard deviation (SD) of the hourly averaged MLH, given in Fig. 6, taken over 20 days in July and 24 days in August at the TLV site, and 30 days in July and 30 days in August at the BD site. An hourly SD average from both sites (dotted black line) ranges between 22 and $35 \%$.

land, reducing the thermal buoyancy and consequently causing subsidence of the MLH.

Figure 6 demonstrates the prevailing influence of the SBF as it progresses from the shoreline (TLV) to inland (BD). Lieman and Alpert (1993) produced similar results for the coastal summer MLH in Israel based on the MM4 3-D mesoscale mathematical model. They analyzed the MLH spatial cross section evolution over Israel referring to three points: onshore (10 km from the shoreline), inland (mountains, $50 \mathrm{~km}$ inland from the shoreline), and the valley ( $80 \mathrm{~km}$ inland from the shoreline). They found that the onshore MLH is not as deep as it is inland. As the SBF penetrates land, the onshore MLH tends to become even shallower, while the inland convection increases.

Uzan and Alpert (2012) showed comparable results for the summer months of June-October by the aforementioned LAP-3000 acoustic radar site. While the SBF penetrated inland, the average wind speed of the atmospheric mixed layer strengthened (between 05:00 and 12:00 UTC), generating a gradual drop of $150 \mathrm{~m}$ of the MLH between the hours 05:00 and 11:00 UTC.

In contrast to former research by Dayan and LifshitzGolden (2002), indicating that the inland BD MLH is $50 \mathrm{~m}$ higher than the onshore LAP-3000 site (Fig. 1), in the present 


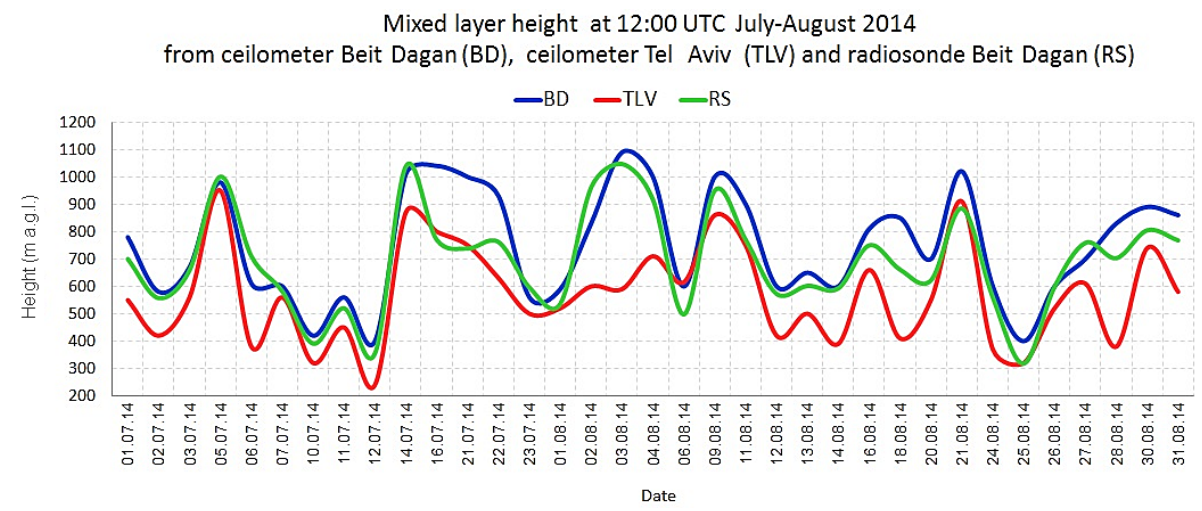

Figure 8. The diurnal MLH at 12:00 UTC between July and August 2014, from ceilometers at TLV and BD sites, compared to the MLH derived from the radiosonde. The evaluation was based on 35 days between 1 July and 31 August 2014 with full data from the three instruments.

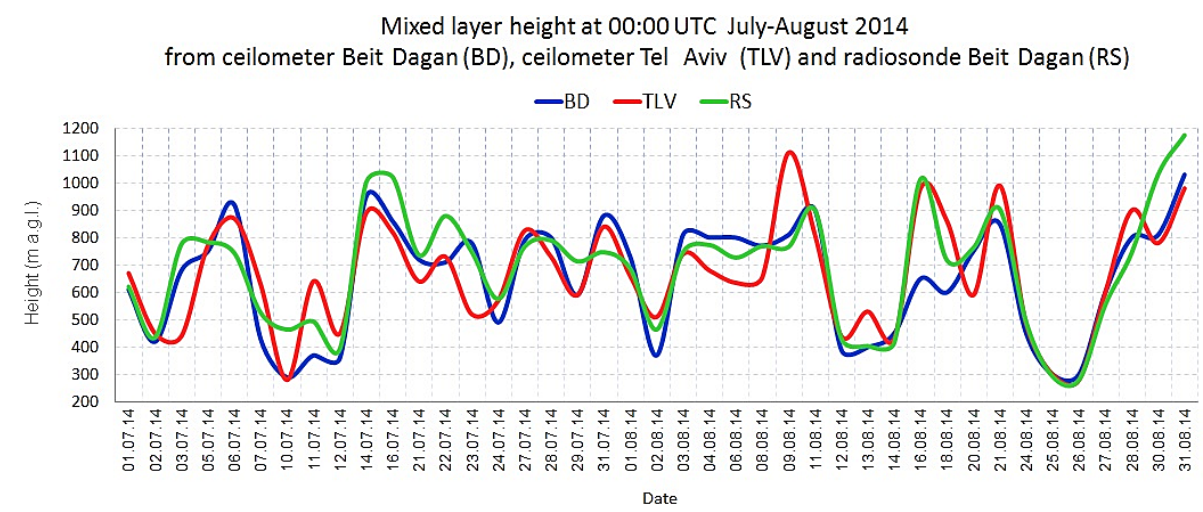

Figure 9. Same as Fig. 8 but for 00:00 UTC based on 41 days between 1 July and 31 August 2014 with full data from the three instruments.

study, it was found that the inland BD MLH tends to be $200 \mathrm{~m}$ higher than the TLV onshore site. The high MLH difference in the current study may be partially attributable to the less developed, and therefore weaker thermals, $50 \mathrm{~m}$ from the shoreline at the TLV site, compared to the potential of thermal development $7.5 \mathrm{~km}$ inland at the BD site. Another relevant point is the stronger temperature gradient (sea-land temperature difference) feasible $7.5 \mathrm{~km}$ inland at the BD site, compared to the onshore site, which was only $50 \mathrm{~m}$ from the shoreline. After sunset (around 16:30 UTC), the reduction of solar radiation weakens both the sea breeze and the thermals. Consequently, the MLH subsides due to the prevailing high synoptic system, known as the high to the west (Alpert et al., 2004). As a result, the onshore and inland MLH coincide both at the height of about $650 \mathrm{~m}$ a.g.l. between sunset and sunrise.

Figure 7 presents the standard deviation (SD) of the mean MLH (given in Fig. 6). Apparently, the lowest SD values are attributed to SBF penetration from the TLV site inland, ruling over the mixing layer at the BD site.

\subsection{Radiosonde comparison}

To verify our MLH calculations, we compared the mean MLH diurnal cycle, given in Fig. 6, with the RS profiles (Figs. 8 and 9). The RS is launched twice a day (00:00 and 12:00 UTC) by the Israeli Meteorological Service (IMS), which is fortuitously located right next to the BD ceilometer. The radiosonde files were downloaded from a site at the University of Wyoming (http://weather.uwyo.edu/upperair/ sounding.html). The definition of the MLH from the RS profiles was based on Stull (1988), and referenced by temperature (inversion layer), relative humidity (significant drop), wind speed (strong wind shear), and virtual temperature (increase).

As expected, the correlation of MLH at the BD site, with $R^{2}=0.82$ for 12:00 UTC and $R^{2}=0.79$ for 00:00 UTC, was higher than at the TLV site, with $R^{2}=0.62$ for 12:00 UTC and $R^{2}=0.63$ for 00:00 UTC (Figs. 10 and 11). In contrast to the ceilometers' high resolution reporting (every $10 \mathrm{~m}$ ) the resolution of the RS, the output file depends on the atmospheric vertical velocity. Therefore an approximate estimation of the inversion height was not entirely possible. 

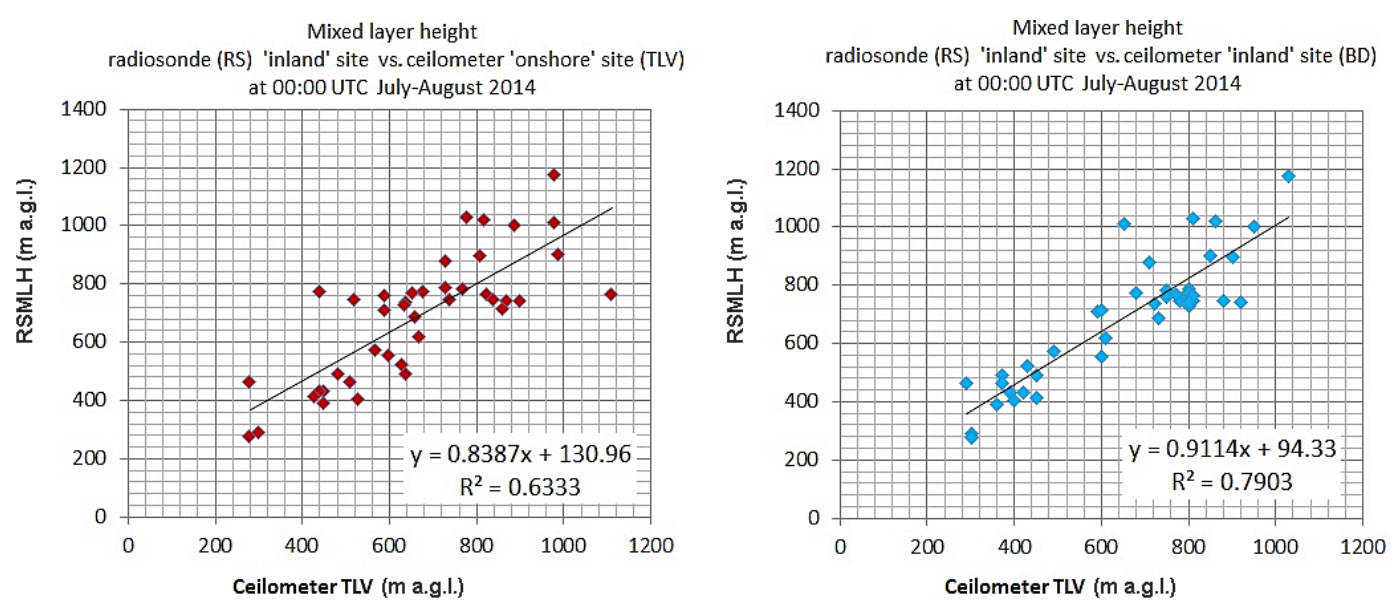

Figure 10. Correlation values between MLH from radiosonde (RS) profiles at 00:00 UTC, the onshore Tel Aviv (TLV) ceilometer, and the $7.5 \mathrm{~km}$ inland Beit Dagan (BD) ceilometer. The BD ceilometer is adjacent to the RS launching site.
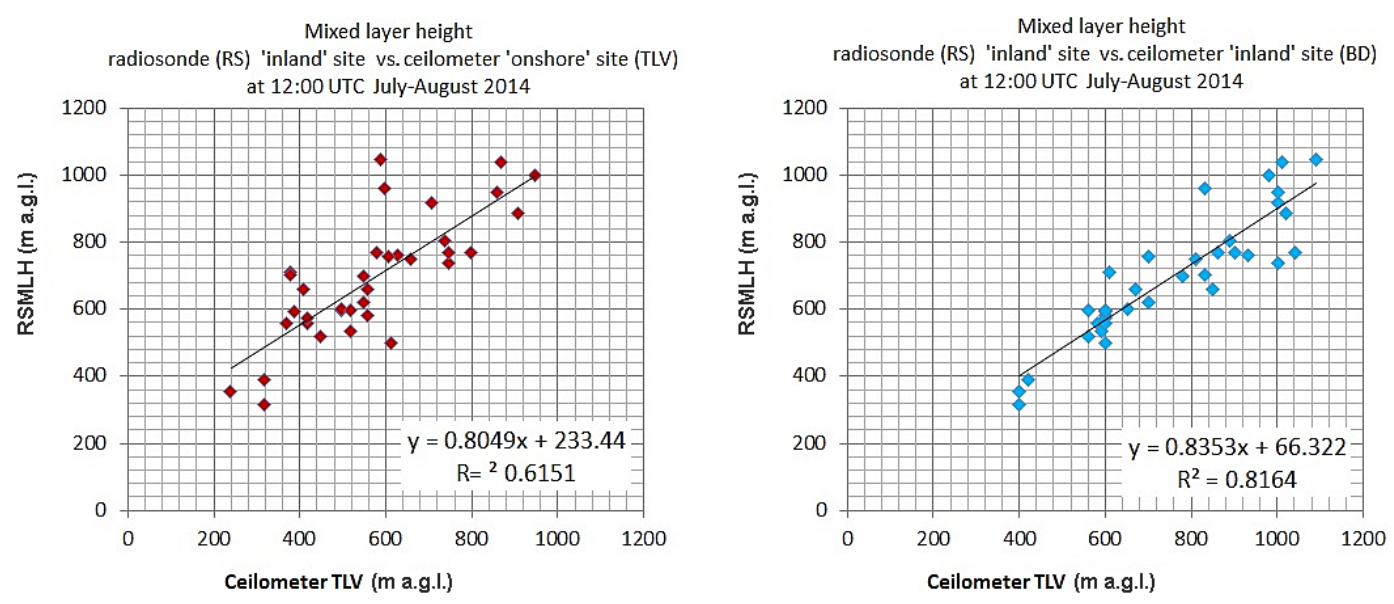

Figure 11. Same as Fig. 10 but for 12:00 UTC.

Overall, however, the comparisons of RS profiles inland and onshore are in accordance with Fig. 6. The MLH derived by the ceilometer data and validated by the RS profiles reveals the significance of the SBF on the evolution of the $\mathrm{MLH}$, through a short path of $7.5 \mathrm{~km}$. While there is a difference of $200 \mathrm{~m}$ between the onshore and inland MLH, at both sites, the overall evolution of the MLH is the same, high after sunrise, and drops after the SBF penetration, remaining at a fairly constant height of about $650 \mathrm{~m}$ a.g.l.

\subsection{Cloud cover}

Another issue is the significant difference in the cloud coverage at the two measuring sites, as demonstrated in Fig. 12. Cloud coverage plays an important role in heat balance as it reduces the solar radiation flux that creates the atmospheric buoyancy force. Consequently, cloud coverage influences the atmospheric thermals' development responsible for the extension of the MLH. The thermals' development is hindered once the SBFs coincide. Therefore, we presume cloud cover has a larger effect on the MLH development $7.5 \mathrm{~km}$ from the shoreline in the BD site than $50 \mathrm{~m}$ from the shoreline in the TLV site. After sunset, as the ground cools down, cloud cover may decelerate the release of the sensitive heat and the weakening of the thermals.

In Israel, cloud detection is done mainly by eye observation limited by specific observation points and by time (difficult at night hours). To address the severe lack of cloudiness data, the daily ceilometer plots during JulyAugust 2014 were analyzed for four time periods as follows: pre-sunrise (00:00-03:00 UTC), after sunrise (03:0009:00 UTC), midday time (09:00-16:00 UTC), and after sunset (16:00-00:00 UTC). Each half-hour profile was scored for cloud coverage as follows: 1 for cloud presence and 0 for no clouds. The analysis was only performed for days with complete data from both ceilometers ( 20 days in July and 22 days in August). 

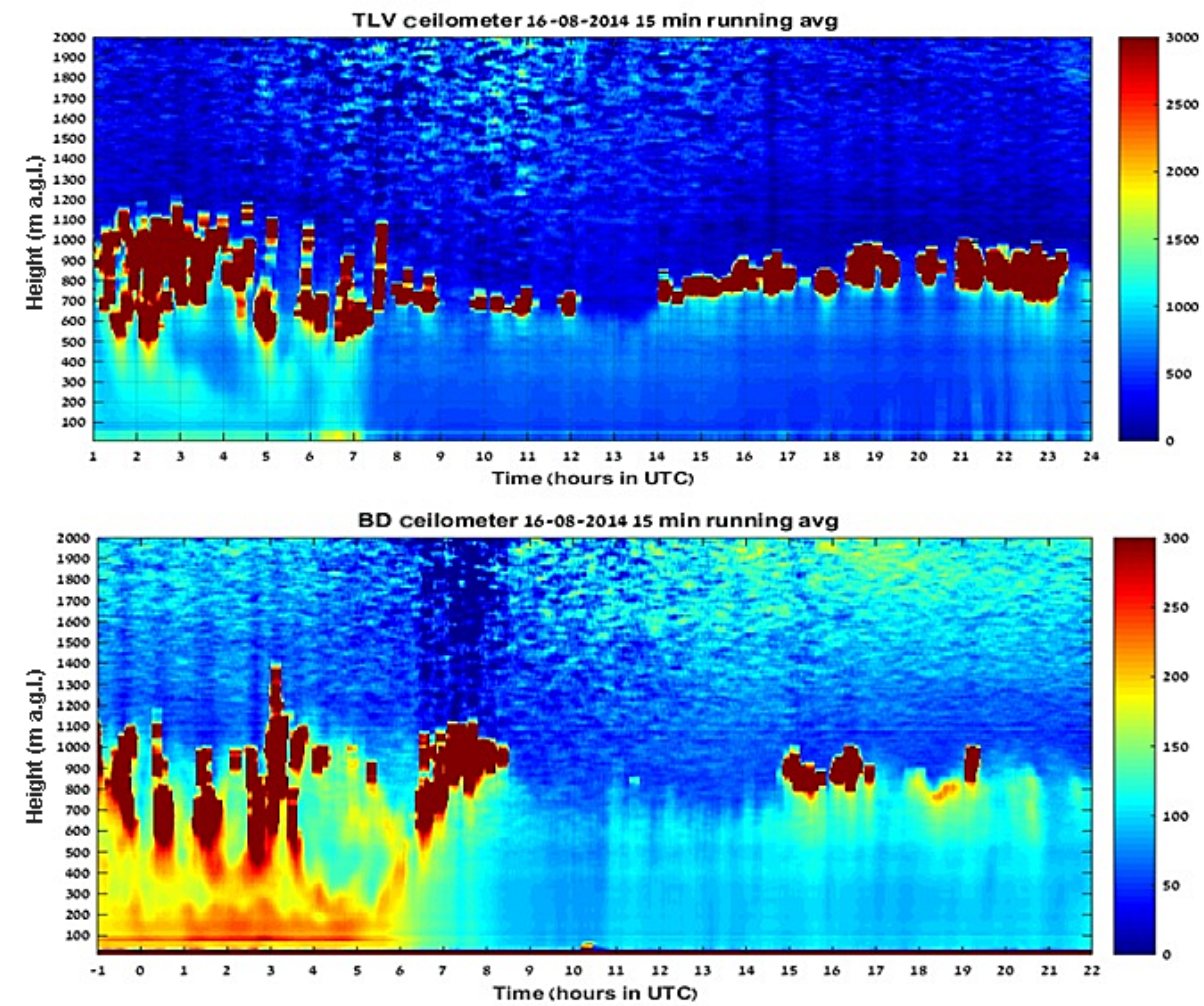

Figure 12. An example of differences in cloud cover on 16 August 2014, measured by the onshore TLV ceilometer (top panel) and the inland $\mathrm{BD}$ ceilometer (bottom panel). The BD plot is shifted by $2 \mathrm{~h}$ to convert to UTC time.

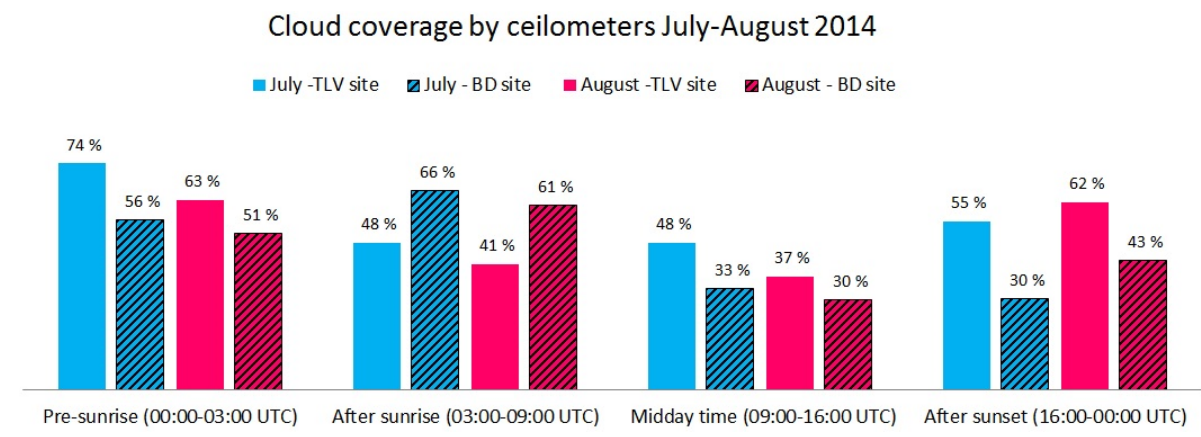

Figure 13. Cloud cover based on half-hourly averaged ceilometer plots from the TLV (onshore) and BD (inland) sites between July and August 2014. Each half hourly profile was scored as follows: 1 for cloud presence and 0 for no clouds. The estimation was done on days with complete data from both ceilometers (20 days in July and 22 days in August).

Results (illustrated in Fig. 13) show that the TLV site was cloudier than the BD site (except for after sunrise). The only time that August was cloudier than July was after sunset. This finding may explain the difference between the MLH at the BD site after sunset (Fig. 6), when the MLH was higher in August than in July.

\section{Conclusions and discussion}

The aim of this study was to investigate the EM MLH diurnal cycle using high-resolution CL31 ceilometers. Ceilometers were originally intended for cloud detection; however, in the last decade, they have proved to be beneficial for detecting the atmospheric MLH. Ceilometers are characterized by their ability to produce high temporal (every $15 \mathrm{~s}$ ) and spatial (every $10 \mathrm{~m}$ ) resolution measurements. The ceilometers' output is influenced by cloud presence and all types of atmospheric 
particulate matter, including natural dust and anthropogenic aerosols.

For the first time, a comparison done between measurements taken simultaneously from ceilometers onshore and inland $(7.5 \mathrm{~km}$ apart) on flat terrain showed differences of about $200 \mathrm{~m}$ between the onshore and inland mean MLH diurnal cycle, mainly during daylight hours.

The summer months (July-August) of 2014 reveal the MLH evolution process to be quite persistent; after sunrise (03:00 UTC) the thermals extend the MLH up to $930 \mathrm{~m}$ a.g.1. at the $\mathrm{BD}$ inland site and $750 \mathrm{ma.g} .1$. at the onshore TLV site. As the SBF penetrates inland (about $4 \mathrm{~h}$ later), the MLH eventually subsides to $740 \mathrm{~m}$ a.g.l. at the BD inland site and $600 \mathrm{~m}$ a.g.l. at the onshore TLV site. Finally, after sunset (16:30 UTC), the MLHs of both inland and onshore sites coincide at 650-700 $\mathrm{m}$ a.g.l. until sunrise.

Verification by in situ adjacent RS measurements shows good correlation with the MLH ceilometer detection, reinforcing the MLH difference found between the onshore and inland sites.

For the first time, the ceilometer measurements revealed a significantly cloudy summer of 2014, contrary to the characteristically clear sky commonly expected. The high resolution of the ceilometers enabled the identification of a higher cloud cover after sunset in August, compared to July, at the inland (BD) site. This finding was related to the gap found between the mean MLH of July (lower) and August (higher) at the inland site.

Fortunately the number of ceilometers in Israel is growing rapidly, offering increasing detailed information on the local evolution pattern of the MLH height at several locations. Ceilometer MLH assessment can be utilized to assist in the estimation of pollution risk analysis and serve as test profiles for dust models.

Further investigation of the cloud types and layers will aid in interpreting the thermal heat flux difference influencing MLH evolvement, especially on cloudy days. The quality ceilometer output in the lower height range (less than $100 \mathrm{~m}$ a.g.1.) should be further investigated, especially for ceilometers deployed in places of higher topography when the MLH is quite low, such as during the Israeli summer. Finally, it is essential to understand the potential of using ceilometers as tools for validating mathematical models of weather forecast and air pollution dispersion.

\section{Data availability}

The ceilometer data sets are available on request to the corresponding author. The radiosonde data files were downloaded from the website of the University of Wyoming (http: //weather.uwyo.edu/upperair/sounding.html). Ground monitoring meteorological data are available at: http://www.ims. gov.il/IMSEng/CLIMATE/LongTermInfo/ (IMS, Israel Meteorological Service).
Acknowledgements. We wish to thank the Israeli Meteorological Service (IMS) and the Israeli Air Force (IDF) for their data and collaboration. Special thanks is expressed to Nir Stav (IMS) for his fruitful advice, Anat Baharad (Tel Aviv University) for the assistance with the MATLAB scripts, and Pavel Kunin (Tel Aviv University) for the WRF-Chem model data.

Edited by: V. Amiridis

Reviewed by: two anonymous referees

\section{References}

Alpert, P. and Rabinovich-Hadar, M.: Pre- and post-frontal lines A meso gamma scale analysis over south Israel, J. Atmos. Sci., 60, 2994-3008, 2003.

Alpert, P., Osetinsky, I., Ziv, B., and Shafir, H.: A new seasons definition based on the classified daily synoptic systems: An example for the Eastern Mediterranean, Int. J. Climatol., 24, 1013-1021, 2004.

Angelini, F., Barnaba, F., Landi, C. T., Caporaso, L., and Gobbi, P. G.: Study of atmospheric aerosols and mixing layer by lidar, Radiat. Prot. Dosimetry, 137, 275-279, doi:10.1093/rpd/ncp219, 2009.

Atkinson, B. W.: Meso-scale atmospheric circulation, Academic Press, London, UK, 495 pp., 1981.

Baars, H., Ansmann, A., Engelmann, R., and Althausen, D.: Continuous monitoring of the boundary-layer top with lidar, Atmos. Chem. Phys., 8, 7281-7296, doi:10.5194/acp-8-7281-2008, 2008.

Carnevale, C., Finzi, G., Pisoni, E., Volta, M., Kishcha, P., and Alpert, P.: Integrating Saharan dust forecasts into a regional chemical transport model: a case study over Northern Italy, Sci. Total Environ., 417-418, 224-231, doi:10.1016/j.scitotenv.2011.12.031, 2012.

Chuen-Meei, G., Wu, Y. H., Gross, B. M., Arend, M., Moshary, F., and Ahmed, S.: A comparison of estimated mixing height by multiple remote sensing instruments and its influence on air quality in urban regions, IGARSS'10 Int. Geosci. Remote. Se., Honolulu, Hawaii, USA, 25-30 July 2010, 730-733, 2010.

Cohn, S. A. and Angevine, W. A.: Boundary layer height and entrainment zone thickness measured by lidars and wind-profiling radars, J. Appl. Meteor., 39, 1233-1247, 2000.

Dayan, U. and Koch, J.: A synoptic analysis of the meteorological conditions affecting dispersion of pollutants emitted from tall stacks in the coastal plain of Israel, Atmos. Environ., 26, 25372543, 1992.

Dayan, U., Lifshitz-Golden, B., and Pick, K.: Spatial and structural variation of the atmospheric boundary layer during summer in Israel-profiler and rawinsonde measurements, B. Am. Meteorol. Soc., 41, 447-457, 2002.

Emeis, S. and Schäfer K.: Remote sensing methods to investigate boundary-layer structures relevant to air pollution in cities, Bound.-Lay. Meteorol., 121, 377-385, doi:10.1007/s10546-0069068-2, 2006.

Emeis, S., Schäfer, K., and Münkel, C.: Surface-based remote sensing of the mixing-layer height - a review, Meteorol. Z., 17, 621630, doi:10.1127/0941-2948/2008/0312, 2008. 
Flaounas, E., Kotroni, V., Lagouvardos, K., Klose, M., Flamant, C., and Giannaros, T. M.: Assessing atmospheric dust modelling performance of WRF-Chem over the semi-arid and arid regions around the Mediterranean, Atmos. Chem. Phys. Discuss., doi:10.5194/acp-2016-307, in review, 2016.

Haeffelin, M., Angelini, F., Morille, Y., Martucci, G., Frey, S., Gobbi, G. P., Lolli, S., O’Dowd, C. D., Sauvage, L., XuerefRémy, I., Wastine, B., and Feist, D. G.: Evaluation of mixing height retrievals from automatic profiling lidars and ceilometers in view of future integrated network in Europe, Bound.-Lay. Meteorol., 143, 49-75, 2012.

Kotthaus, S., O'Connor, E., Münkel, C., Charlton-Perez, C., Haeffelin, M., Gabey, A. M., and Grimmond, C. S. B.: Recommendations for processing atmospheric attenuated backscatter profiles from Vaisala CL31 ceilometers, Atmos. Meas. Tech., 9, 37693791, doi:10.5194/amt-9-3769-2016, 2016.

Leventidou, E., Zanis, P., Balis, D., Giannakaki, E., Pytharoulis, I., and Amiridis, V.: Factors affecting the comparisons of planetary boundary height retrievals from CALIPSO, ECMWF and radiosondes over Thessaloniki Greece, Atmos. Environ., 74, 360$366,2013$.

Lieman, R. and Alpert, P.: Investigation of the planetary boundary layer height variations over complex terrain, Bound.-Lay. Meteorol., 62, 129-142, 1993.

Ludwig, F. L.: A review of coastal zone meteorological processes important to the modeling of air pollution, in: Air pollution modeling and its application IV, 7, 225-258, 1983.

Münkel, C., Emeis, S., Muller, J. W., and Schäfer, K.: Aerosol concentration measurements with a lidar ceilometer: results of a one year measuring campaign, P. Soc. Photo-Opt. Ins., 5235, 486496, doi:10.1117/12.511104,2004.

Schween, J. H., Hirsikko, A., Löhnert, U., and Crewell, S.: Mixinglayer height retrieval with ceilometer and Doppler lidar: from case studies to long-term assessment, Atmos. Meas. Tech., 7, 3685-3704, doi:10.5194/amt-7-3685-2014, 2014.
Stull, R. B.: An introduction to boundary layer meteorology, Kluwer Academic Publishers, the Netherlands, 666 pp., 1988.

Tang, G., Zhu, X., Hu, B., Xin, J., Wang, L., Münkel, C., Mao, G., and Wang, Y.: Impact of emission controls on air quality in Beijing during APEC 2014: lidar ceilometer observations, Atmos. Chem. Phys., 15, 12667-12680, doi:10.5194/acp15-12667-2015, 2015.

Uzan, L.: Investigation of the Thermal Boundary Layer over Hadera from a LAP-3000 profiler under different synoptic and air pollution conditions, M.S. Thesis, Tel Aviv University, Israel, 93 pp., 2007.

Uzan, L. and Alpert P.: The coastal boundary layer and air pollution - A high temporal resolution analysis in the East Mediterranean Coast, Open Atmos. Sci. J., 6, 9-18, 2012.

Van der Kamp, D. and Mckendry, I. G.: Diurnal and seasonal trends in convective mixed layer heights estimated from two years of continuous ceilometers observations in Vancouver BC, Bound.Lay. Meteorol., 137, 459-475, 2010.

Wiegner, M. and Gasteiger, J.: Correction of water vapor absorption for aerosol remote sensing with ceilometers, Atmos. Meas. Tech., 8, 3971-3984, doi:10.5194/amt-8-3971-2015, 2015.

Wiegner, M., Emeis, S., Freudenthaler, V., Heese, B., Junkermann, W., Münkel, C., Schäfer, K., Seefeldner, M., and Vogt, S.: Mixing layer height over Munich, Germany: Variability and comparisons of different methodologies, J. Geophys. Res., 111, D13201, doi:10.1029/2005JD006593, 2006.

Wiegner, M., Madonna, F., Binietoglou, I., Forkel, R., Gasteiger, J., Geiß, A., Pappalardo, G., Schäfer, K., and Thomas, W.: What is the benefit of ceilometers for aerosol remote sensing? An answer from EARLINET, Atmos. Meas. Tech., 7, 1979-1997, doi:10.5194/amt-7-1979-2014, 2014. 